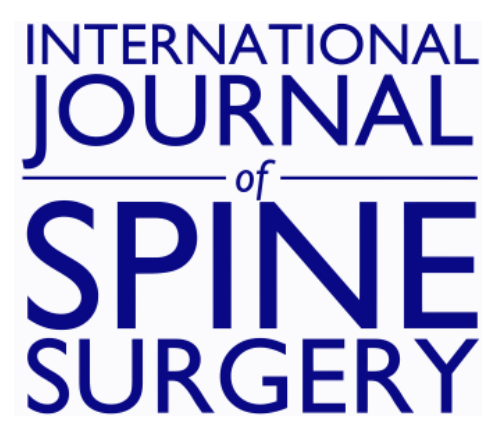

\title{
Brucellosis of the Spine in Children--An Analysis of 5 Children From an Endemic Setting
}

Justin Arockiaraj, Magdalenal Arockiaraj, Walid Ismail Attia and Khaled N. Almusrea

Int J Spine Surg 2021, 15 (4) 840-847

doi: https://doi.org/10.14444/8108

http://ijssurgery.com/content/15/4/840

This information is current as of April 26, 2023.

Email Alerts Receive free email-alerts when new articles cite this article. Sign up at:

http://ijssurgery.com/alerts 


\title{
Brucellosis of the Spine in Children-An Analysis of 5 Children From an Endemic Setting
}

\author{
JUSTIN AROCKIARAJ, MS, ${ }^{1}$ MAGDALENAL AROCKIARAJ, MD ${ }^{2}$ WALID ISMAIL ATTIA, MD, MSC, \\ PHD,${ }^{1}$ KHALED N. ALMUSREA, B.MED.SC, MD, FRCSC ${ }^{1}$ \\ ${ }^{I}$ Spine Surgery Department, National Neurosciences Institute, King Fahad Medical City, Riyadh, Kingdom of Saudi Arabia, ${ }^{2}$ Paediatric Emergency Department, \\ King Fahad Medical City, Riyadh, Kingdom of Saudi Arabia
}

\begin{abstract}
Background: Brucellosis of the spine is quite common among adults in endemic regions. The incidence of brucellosis of the spine affecting children is very rare. This article describes the clinical characteristics, diagnosis, management and outcome of children with brucellosis of the spine. It also aims to create awareness among all health care professionals, especially spine surgeons, regarding this rare entity.

Methods: This was a retrospective study of children aged less than 15 years who were diagnosed and treated for brucellosis of the spine. Confirmed cases of brucellosis in children who had completed a full course of a triple-drug regimen as per Centers for Disease Control and Prevention (CDC) guidelines were included. Outcome analysis included both clinical and radiological measures. Clinical measures included pain, neurological status, and return to school. Resolution of the abscess and sclerosis of the involved vertebra were taken as the radiological measure.

Results: A total of 5 children (4 boys and 1 girl) with an average age of 10 years, ranging from 6 to 14 years, fulfilled the inclusion criteria. The mean follow-up period was 32 months. All children presented with fever, back pain, and constitutional symptoms. Two of them had neurological deficits, and posttreatment, they improved to near normal neurological status. Only 1 child with an epidural abscess compressing the lumbar canal required surgical intervention. All the children were treated with a triple-drug regimen. Longer duration of treatment (14 months) was given for 2 children with history of relapse. All children were healed of the disease without any sequalae or relapse.

Conclusions: Blood culture and standard agglutination tests are mandatory for the diagnosis of brucellosis. Children tolerated the triple-drug regimen well. Prolonged duration of treatment was required for children with relapse. Health education to all treating health care professionals and parents is of paramount importance for treatment and control of this endemic disease.
\end{abstract}

Other \& Special Categories

Keywords: Brucellosis, spine, diagnosis, treatment

\section{INTRODUCTION}

Brucellosis has been declared endemic in the Middle East and along the Mediterranean rim. Prevalence of brucellosis is approximately 10 per 100000 in endemic countries. ${ }^{1,2}$ The incidence of brucellosis in the Kingdom of Saudi Arabia is estimated as 70 per $100000 .^{3}$ Spinal involvement is the most common musculoskeletal manifestation of brucellosis, which is very common in adults more than 50 years of age. Brucellosis of the spine is rare among children. Few studies on paediatric spinal brucellosis have been published. ${ }^{4,5}$ This article describes the clinical characteristics, diagnosis, management, and outcome of children with brucellosis of the spine. It also aims to create awareness among all health care professionals, especially spine surgeons.

\section{MATERIALS AND METHODS}

A retrospective study was conducted from 2012 to 2019 (8-year period) in our tertiary care center of children less than 15 years of age who were treated for infective spondylodiscitis. Only confirmed cases of brucellosis of the spine (by blood culture or standard agglutination test [SAT] $>1: 160$ ) as per the Centers for Disease Control and Prevention (CDC) definition ${ }^{6}$ and those who had completed treatment with adequate follow up were included in the study. Demography, history of back pain, fever associated with any constitutional symptoms like loss of appetite, loss of weight, history of brucellosis, and treatment was documented. History of consumption of raw or unpasteurized animal milk, contact with infected animals or animal products, and family history of brucellosis was noted. Neurological status 
Table 1. Demography, clinical presentation, and level of involvement.

\begin{tabular}{|c|c|c|c|c|c|}
\hline $\begin{array}{l}\text { Serial } \\
\text { No. }\end{array}$ & Age & Sex & Clinical presentation & Level of involvement & $\begin{array}{c}\text { History of previous } \\
\text { treatment }\end{array}$ \\
\hline 1 & 6 & Male & Fever, neck pain, torticollis. No neurological deficits. & $\mathrm{Cl}-2$ & No \\
\hline 2 & 4 & Male & Fever, low back ache with no neurological deficits. & L5-S1 & Partially treated for $6 \mathrm{wk}$ \\
\hline 3 & 14 & Male & Fever, low back ache with no neurological deficits. & L4-5 & No \\
\hline 4 & 10 & Female & $\begin{array}{l}\text { As per outside report, she was paraplegic with sensory } \\
\text { level at thoracic } 5 \text { level. She was treated with } \\
\text { gentamycin, doxycycline, and rifampicin. } \\
\text { At admission, she had gradually improved in her } \\
\text { neurology with Medical Research Council grade } 3 / 5 \\
\text { power in hip, knee, and ankle level. She was on ankle } \\
\text { foot orthosis. }\end{array}$ & Thoracic spine epidural abscess & No \\
\hline 5 & 14 & Male & $\begin{array}{l}\text { Fever, lower limb weakness, ascending paralysis. } \\
\text { At admission, he had bilateral foot drop and weak hip } \\
\text { and knee flexors, Medical Research Council grade } 3 / 5 \\
\text { power. }\end{array}$ & Brain and spinal cord & $\begin{array}{l}\text { Partially treated for } 3 \mathrm{wk} \text {, } \\
\text { ( } 2 \text { episodes) }\end{array}$ \\
\hline
\end{tabular}

assessment was done as per the American Spinal Injury Association (ASIA) impairment scale. ${ }^{7}$

Outcome measures included clinical, biochemical, and radiological parameters. Reduction in pain, neurological status, and return to school were the clinical parameters. Decrease in erythrocyte sedimentation rate and C-reactive protein levels were the biochemical markers. Radiological markers of healing included resolution of abscess, sclerosis of the vertebrae, and reduction in signal intensity. ${ }^{8}$

\section{RESULTS}

A total of 5 children ( 4 boys and 1 girl) with an average age of 10 years, ranging from 6 to 14 years, fulfilled the inclusion criteria. Clinically, all of them presented with fever, back pain, and constitutional symptoms. Their demographic data, clinical presentation, and level of involvement are shown in Table 1. Radiological features, blood investigations, and their treatment are described in detail (Table 2). All 5 of them had history of consumption of raw milk, 3 of them had history of contact with infected sheep, and 2 of them presented with a positive family history of brucellosis. Two children had history of being treated for systemic brucellosis with 2 drugs for a period of 6 weeks.

Clinical assessment revealed neurological deficit in 2 children. One child had complete paraplegia and was empirically started on streptomycin injection, rifampicin, and doxycycline, with which he had improved when he had presented to us. The other child had history of 2 episodes of partially treated brucellosis and presented with ascending paralysis. Magnetic resonance imaging (MRI) features for this child with ascending paralysis was suggestive of pure neural involvement with enhancement of nerve roots at the cervical vertebral level and cauda equina. Cerebrospinal fluid culture confirmed the diagnosis of brucellosis for this child, and he was treated with a triple-drug regimen for 14 months.

Radiologically, MRI showed single-level involvement in 3 out of 5 children ( 2 children with lumbar vertebral [Figure 1] involvement and 1 with cervical vertebral involvement). Epidural abscess was seen in 3 out of 5 children, and prevertebral abscess was seen in 2 out of 5 children. MRI of 1 child revealed intradural extramedullary abscess at the thoracic spinal level [Figure 2A, B]. Only 1 child had pure enhancement of nerve roots and cauda equina. MRI features have been described in detail in Table 2.

Only 1 child underwent surgical intervention, while the rest were treated conservatively. Lumbar epidural abscess with significant compression on the dural sac was the indication for surgery.

All the children were diagnosed based on CDC criteria, as per blood culture in 3 out of 5 children ( $60 \%$ positive) and SAT in 5 out of 5 of children (100\% positive). All of them were treated with a combination of streptomycin, rifampicin, doxycycline or trimethoprim TMP, and sulphamethoxazole SMX. The average duration of treatment was 6 months. Two children with relapse (with history of partial treatment for systemic brucellosis) were treated for a longer duration (14 months) with the triple-drug regimen and were healed of the disease without any further relapse.

During the treatment, all children tolerated medications well without any complications and were healed of the disease (Table 2). None of the children had relapse. Both children who had 
Table 2. Investigations and management of the children with brucellosis.

\begin{tabular}{|c|c|c|c|c|c|c|c|c|c|c|c|}
\hline $\begin{array}{l}\text { Serial } \\
\text { No. }\end{array}$ & MRI & $\begin{array}{l}\text { Blood } \\
\text { Culture }\end{array}$ & SAT (level) & IgG & IgM & $\mathrm{Hb}$ & WBC & ESR & CRP & Treatment & $\begin{array}{c}\text { Follow-Up } \\
\text { Duration, mo }\end{array}$ \\
\hline 1 & $\begin{array}{l}\text { Prevertebral abscess } \\
\text { seen in front of the } \\
\mathrm{C} 1-3 \text {. Mild changes } \\
\text { seen over the anterior } \\
\text { aspect of cervical } \\
\text { vertebral body. }\end{array}$ & Positive & Positive $(1 / 160)$ & 24.6 & Positive & 11.7 & 8760 & 39 & 44.2 & $\begin{array}{l}\text { Gentamycin injection } \\
\text { for } 3 \mathrm{wk} \text {, rifampicin, } \\
\text { trimethoprim, and } \\
\text { sulphamethoxazole } \\
\text { for } 6 \text { mo. }\end{array}$ & 24 \\
\hline 2 & $\begin{array}{l}\text { High signal intensity in } \\
\text { T2 and low signal } \\
\text { intensity in T1 seen } \\
\text { in the endplates of } \\
\text { L5-S1 with reduction } \\
\text { of the disc space and } \\
\text { signal intensity } \\
\text { changes seen in the } \\
\text { disc as well. Epidural } \\
\text { abscess compressing } \\
\text { the dural sac from L4 } \\
\text { to S1 (Figure 1). }\end{array}$ & Positive & Positive $(1 / 160)$ & 38.9 & Negative & 11.8 & 7100 & 50 & 38.4 & $\begin{array}{l}\text { L4 laminectomy, } \\
\text { decompression of } \\
\text { bilateral L5 nerve } \\
\text { roots followed by } \\
\text { streptomycin } \\
\text { injection for } 3 \mathrm{wk}, \\
\text { rifampicin, } \\
\text { trimethoprim, and } \\
\text { sulphamethoxazole } \\
\text { for } 14 \text { mo. }\end{array}$ & 36 \\
\hline 3 & $\begin{array}{l}\text { Increase in intensity } \\
\text { and enhancement of } \\
\text { the lower endplate of } \\
\text { L4 in T2 weighted } \\
\text { images. Prominent } \\
\text { epidural enhancement } \\
\text { seen behind L4-L5 } \\
\text { vertebrae. }\end{array}$ & Negative & Positive $(1 / 160)$ & 31.9 & Negative & 14.3 & 3570 & 22 & 0.2 & $\begin{array}{l}\text { Streptomycin injection } \\
\text { for } 3 \mathrm{wk} \text {, rifampicin } \\
\text { and doxycycline for } 6 \\
\text { mo. }\end{array}$ & 32 \\
\hline 4 & $\begin{array}{l}\text { Intradural } \\
\text { extramedullary, } \\
\text { multicystic, abscess } \\
\text { seen extending from } \\
\text { thoracic } 4 \text { to } 10 \text { level } \\
\text { [Figures 2(A) and } \\
\text { 2(B)] }\end{array}$ & Negative & Positive $(1 / 2560)$ & 27.05 & Negative & 12.7 & 3920 & 16 & 9.5 & $\begin{array}{l}\text { Streptomycin injection } \\
\text { for } 3 \mathrm{wk} \text {, rifampicin } \\
\text { and doxycycline for } 6 \\
\text { mo. }\end{array}$ & 30 \\
\hline 5 & $\begin{array}{l}\text { Diffuse enhancement of } \\
\text { nerve roots of } \\
\text { cervical and cauda } \\
\text { equina. }\end{array}$ & Positive & Positive $(1 / 320)$ & 29.86 & Negative & 14.1 & 5120 & 2 & 0.16 & $\begin{array}{l}\text { Streptomycin injection } \\
\text { for } 3 \text { wk, rifampicin } \\
\text { and doxycycline for } \\
14 \text { mo. }\end{array}$ & 36 \\
\hline
\end{tabular}

Abbreviations: CRP, C-reactive protein; ESR, erythrocyte sedimentation rate; Hb, hemoglobin; IgG, immunoglobulin G; IgM, immunoglobulin M; MRI, magnetic resonance imaging; SAT, standard agglutination test; WBC, white blood cells.

Table 3. Outcome analysis of the treated children.

\begin{tabular}{|c|c|c|}
\hline Variable & $\begin{array}{c}\text { Pretreatment } \\
\text { Status }\end{array}$ & $\begin{array}{c}\text { Posttreatment } \\
\text { Status }\end{array}$ \\
\hline $\begin{array}{l}\text { Neurological status } \\
\text { (No. of children } \\
\text { with neurological } \\
\text { deficits: 2) }\end{array}$ & $\begin{array}{l}\text { - ASIA A: } 1 \\
\text { - ASIA B: } 1\end{array}$ & $\begin{array}{l}\text { - ASIA D: } 1 \\
\text { - ASIA E: } 1\end{array}$ \\
\hline Blood parameters & $\begin{array}{l}\text { ESR: } 27.6 \mathrm{~mm} / \mathrm{h} \\
\quad(11-50) \\
\text { CRP: } 18.5 \mathrm{mg} \% \\
(0.2-44.2) .\end{array}$ & $\begin{array}{l}\text { ESR: } 9 \mathrm{~mm} / \mathrm{h} \\
(2-21) \\
\text { CRP: } 2.9 \mathrm{mg} \% \\
(0.14-9.2)\end{array}$ \\
\hline Functional outcome & & $\begin{array}{l}\text { No sequalae: } 3 \\
\text { Mild sequalae: } 1 \text { (pain } \\
\text { not interfering with } \\
\text { work or school) } \\
\text { Moderate sequalae: } 1 \\
\text { (pain not interfering } \\
\text { with work or school } \\
\text { and with mild } \\
\text { neurological } \\
\text { deficits) }\end{array}$ \\
\hline
\end{tabular}

Abbreviations: ASIA, American Spinal Injury Association; CRP, C-reactive protein; ESR, erythrocyte sedimentation rate. neurological deficits improved well (1 recovered completely, and the other reached near normal neurology [ASIA D]). Average follow up for the children was 32 months. The clinical and functional outcome analysis are presented in Table 3.

Health education was given to all the children and their parents regarding the disease, duration of treatment, the need for compliance, and the preventive measures.

\section{DISCUSSION}

Human brucellosis is the commonest zoonotic disease, with an average global incidence up to 500000 people. Most endemic countries have prevalence of more than 10 per 100000 patients. ${ }^{1,2}$ Brucellosis has been declared as an endemic disease in the Mediterranean zone and the Arabian Peninsula. While the developed countries have 


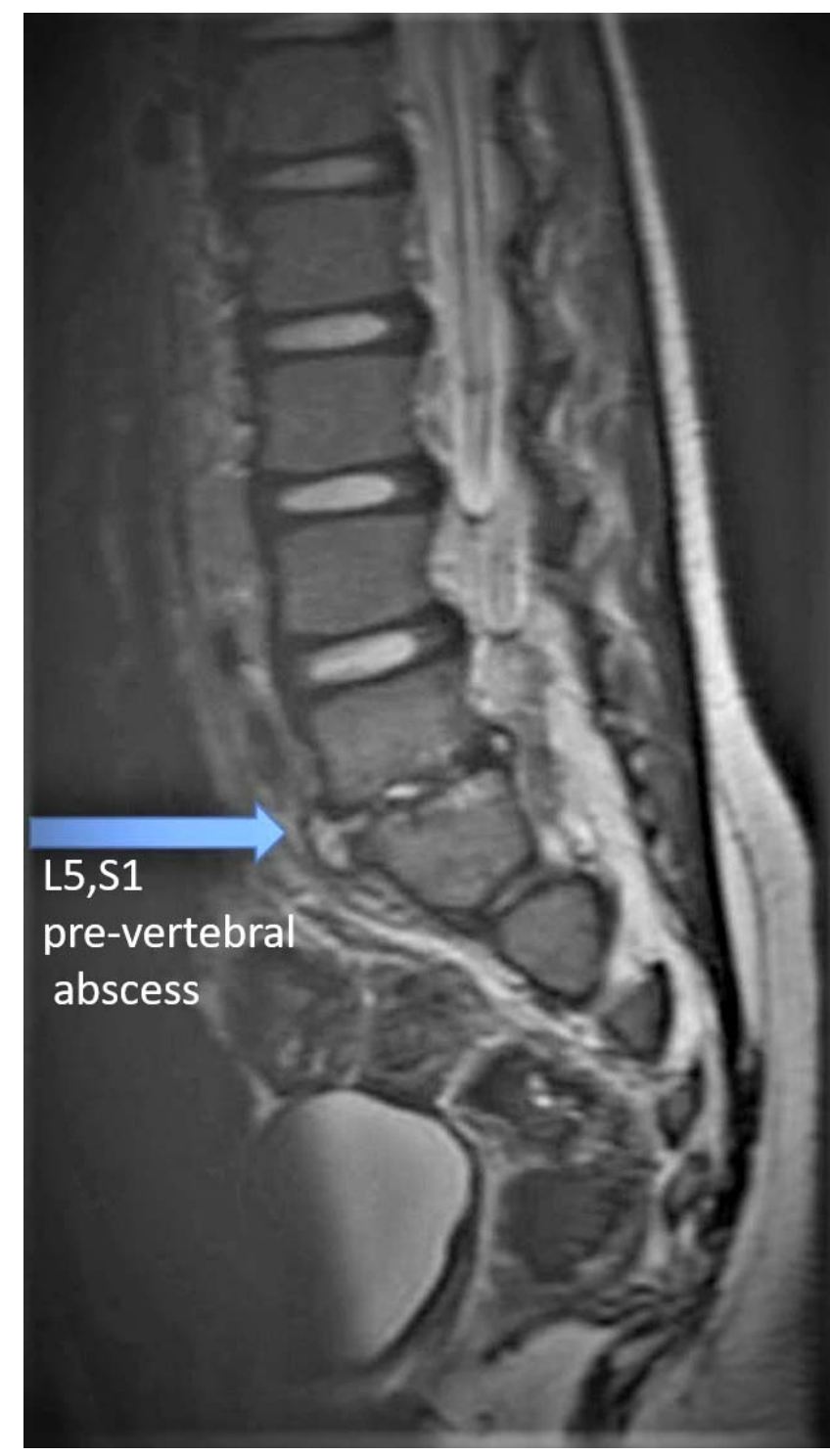

Figure 1. T2 weighted sagittal view magnetic resonance imaging (MRI) with prevertebral abscess,intradiscal abscess at L5,S1 and epidural abscess from the level of L4-S1.

documented lower prevalence, the incidence in endemic countries remain higher. The incidence of brucellosis in the Kingdom of Saudi Arabia is 70 per 100000 population. ${ }^{3}$ Both men and women are equally affected by brucellosis ${ }^{9,10}$; however, children younger than 14 years in the endemic region account for $11 \%-56 \%$ of the patients affected with brucellosis. The reason may be due to lack of pasteurization of milk and exposure to animals in an agricultural society. ${ }^{11}$

The route of transmission to children is commonly oral via consumption of raw or unpasteurized milk and milk products, raw meat, nursing mothers with active brucellosis, and direct contact with infected livestock. ${ }^{12,13}$ Lubani et $\mathrm{al}^{14}$ has reported $100 \%$ chances of developing the disease in those with history of contact with infected animals.

The advantage of early detection of the disease in children is twofold: firstly, to prevent neurological compromise in brucellar spondylodiscitis and, secondly, to prevent relapse. The most common reasons for delay in diagnosis are nonspecific symptoms and variable presentation of the disease. ${ }^{15,16}$ As per the CDC definition for brucellosis, ${ }^{6}$ culture and identification of the Brucella species from clinical specimen is the definitive evidence. The presence of Brucella total antibody titer of greater than or equal to $1: 160$ by SAT or Brucella microagglutination test in 1 or more serum specimens obtained after onset of symptoms is presumptive evidence of brucellosis. Three out of 5 children had definitive diagnoses with identification of the organism in blood culture. All patients had elevated $(>1: 160)$ titer in the SAT. All children had high immunoglobulin G ( $\mathrm{IgG}$ ) enzyme-linked immunosorbent assay (ELISA) antibody titers. Only 1 child with prevertebral abscess revealed immunoglobulin M (IgM) ELISA positivity, proving the fact that most of the spinal involvement in children is chronic. However, the sensitivity of $\mathrm{IgG}$ and IgM ELISA is low for the diagnosis of brucellosis.

Radiologically, spinal brucellosis presents as a focal or diffuse form. Preservation of morphological structure of the vertebra, presence of variable sclerosis, moderate epidural extension, absence of gibbus deformity, and absence of paraspinal abscesses are the key distinguishing features to differentiate brucellar spondylodiscitis from tuberculosis of the spine (radiologically). ${ }^{8}$ Three of our children had epidural abscess, and 3 of them had focal involvement of the vertebrae. None of them had any deformity or paravertebral abscess like the features described above.

Medical management is the key for successful treatment of brucellosis. Our children underwent treatment like Elham et al. ${ }^{12}$ For children more than 8 years old, oral doxycycline ( $4 \mathrm{mg} / \mathrm{kg}$ /day) and rifampicin $(20 \mathrm{mg} / \mathrm{kg} /$ day $)$ was prescribed, and for children under 8 years old, oral trimethoprim TMP (6-8 mg/kg/day), sulphamethoxazole SMX (30-40 mg/kg/day), and rifampicin (20 mg/ $\mathrm{kg} /$ day) were given. ${ }^{17,18}$ All were treated for a 

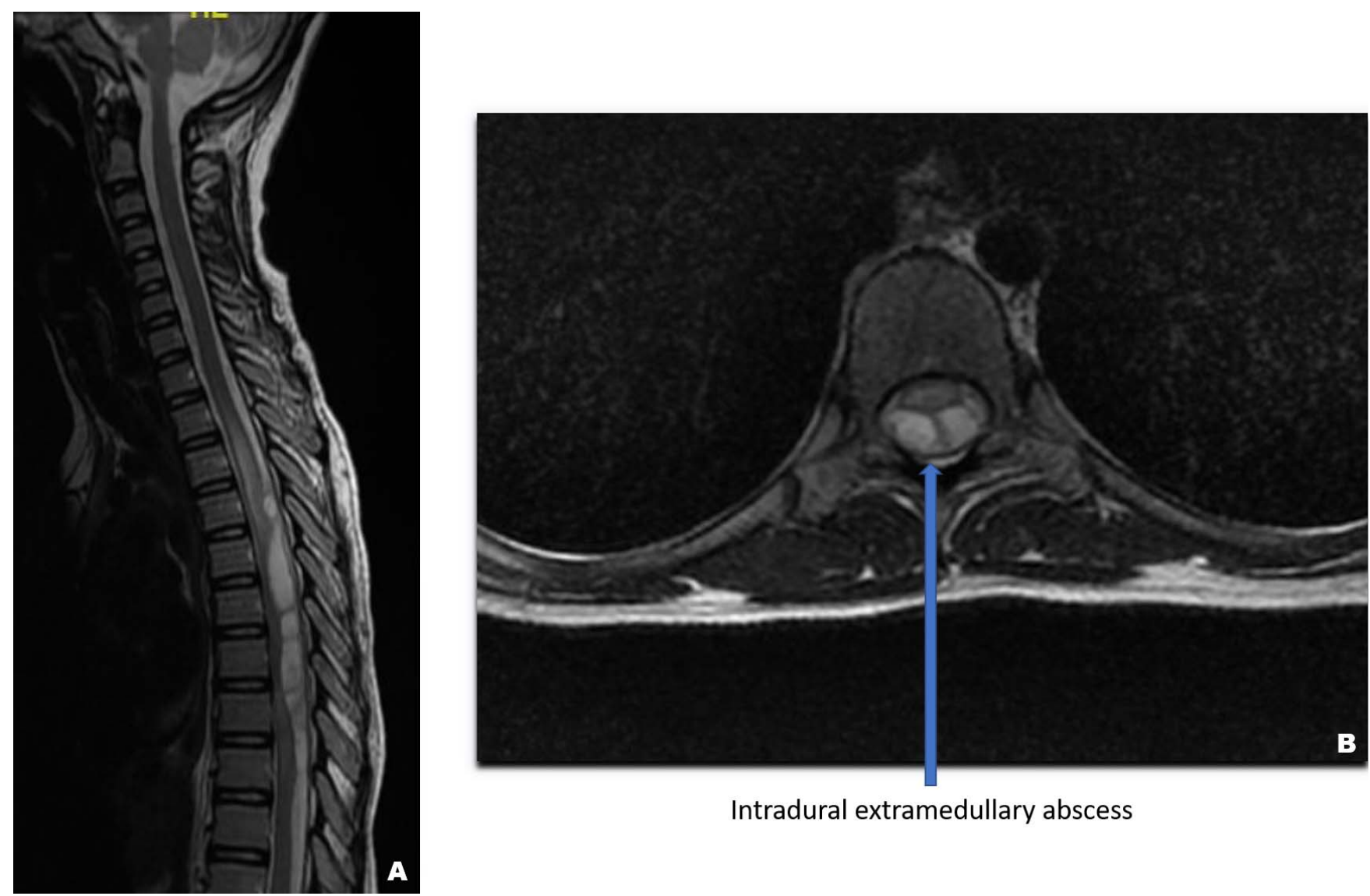

Intradural extramedullary abscess

Figure 2. (A) T2 weighted sagittal view magnetic resonance imaging (MRI) showing evidence of an intradural extramedullary multicystic heterogeneously and peripherally enhancing lesion of multiple areas of diffusion restriction extending from thoracic4 through thoracic10levels. (B) T2 weighted axial view MRI at the level of D7 with intradural extramedullary cystic, septate abscess compressing the cord significantly.

minimum period of 6 months. Only 2 of them with relapse received a longer duration of treatment (14 months). Progressive neurological deficits and severe unrelenting pain are the common indications for surgical intervention. Only 1 child in our series with lumbar epidural abscess with significant compression of the dural sac underwent decompression of the dura and nerve roots at L4-5 level.

The rate of relapse in childhood brucellosis was reported to be $6.6 \%-14 \% .^{14,19,20}$ Noncompliance, inadequate dose, inadequate duration of therapy, and improper combination of antibiotics were the reasons for relapse. Prolonged duration of treatment and appropriate combination of antibiotics have reduced the relapse rate. ${ }^{20}$ In our study, we had 2 children with relapse due to partial treatment. They were treated with a longer duration (14 months) of the triple-drug regimen and were healed of the disease without any further relapse.
Health care professionals should have high suspicion for brucellosis in children presenting with back pain with or without neurological deficits, with or without constitutional symptoms, especially in endemic region. Screening of the other household members of an index case is vital for their early diagnosis.

\section{CONCLUSIONS}

Blood culture and SATs are mandatory for the diagnosis of brucellosis. Children tolerated the triple-drug regimen well. The duration of treatment is prolonged for children with relapse. Health education to all health care professionals and parents is vital to treat and control this endemic disease.

\section{ILLUSTRATION}

A 6-year-old boy was brought by his parents with complaints of neck pain with associated fever for 4 


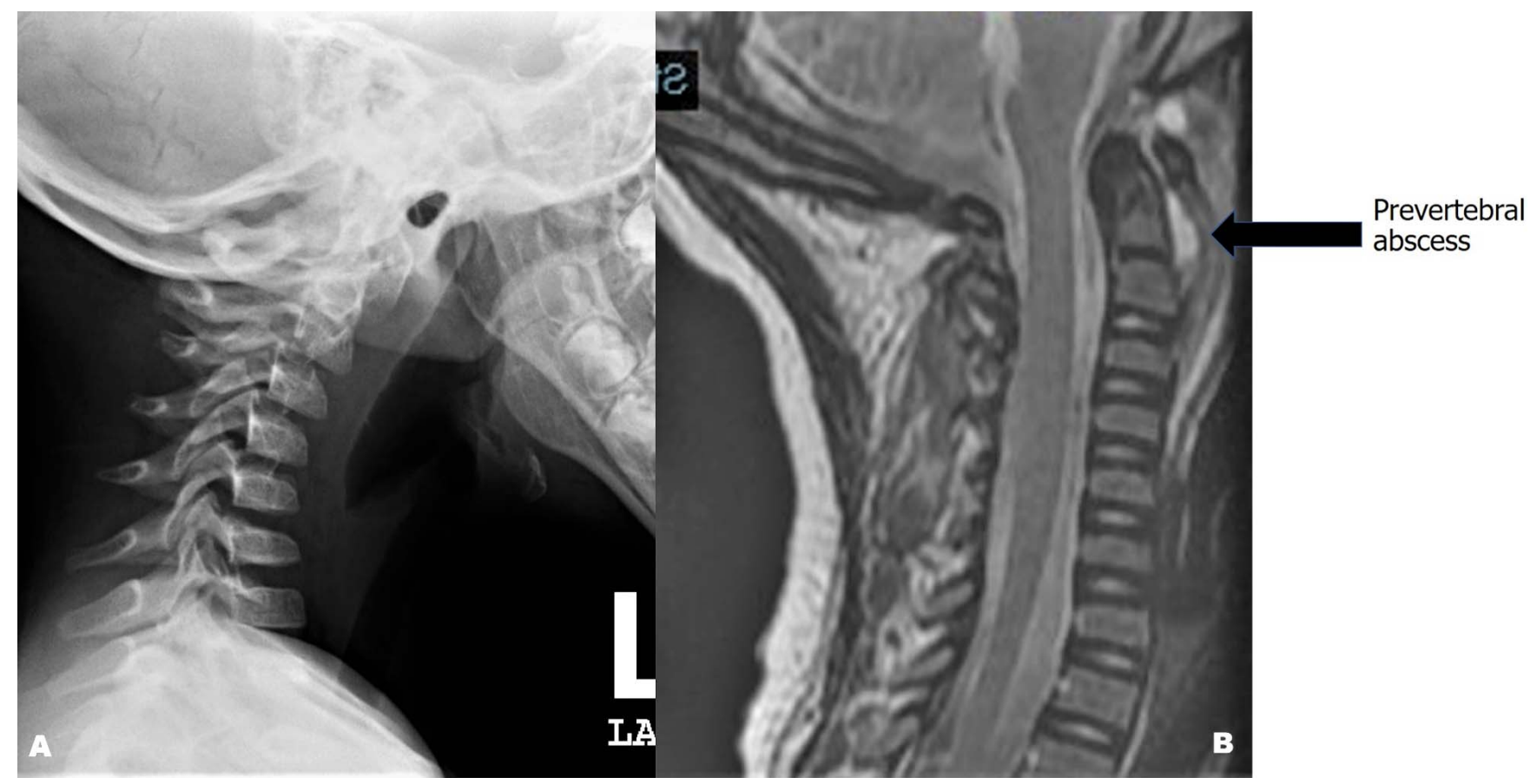

Figure 3. (A) Plain radiograph (lateral view) with reversal of cervical lordosis along with increased retropharyngeal soft tissue shadow. (B) T2 weighted sagittal magnetic resonance imaging (MRI) with prevertebral abscess at the level of C1-3 vertebra.

days. On examination, the child had torticollis, tenderness over the neck, and range of movements of the neck was painful and restricted. There were no neurological deficits. Plain radiograph showed reversal of cervical lordosis with increased retropharyngeal soft tissue shadow (Figure 3A). The MRI revealed a $2.5 \times 1 \mathrm{~cm}$ collection with peripheral enhancement and a central non-enhanc-
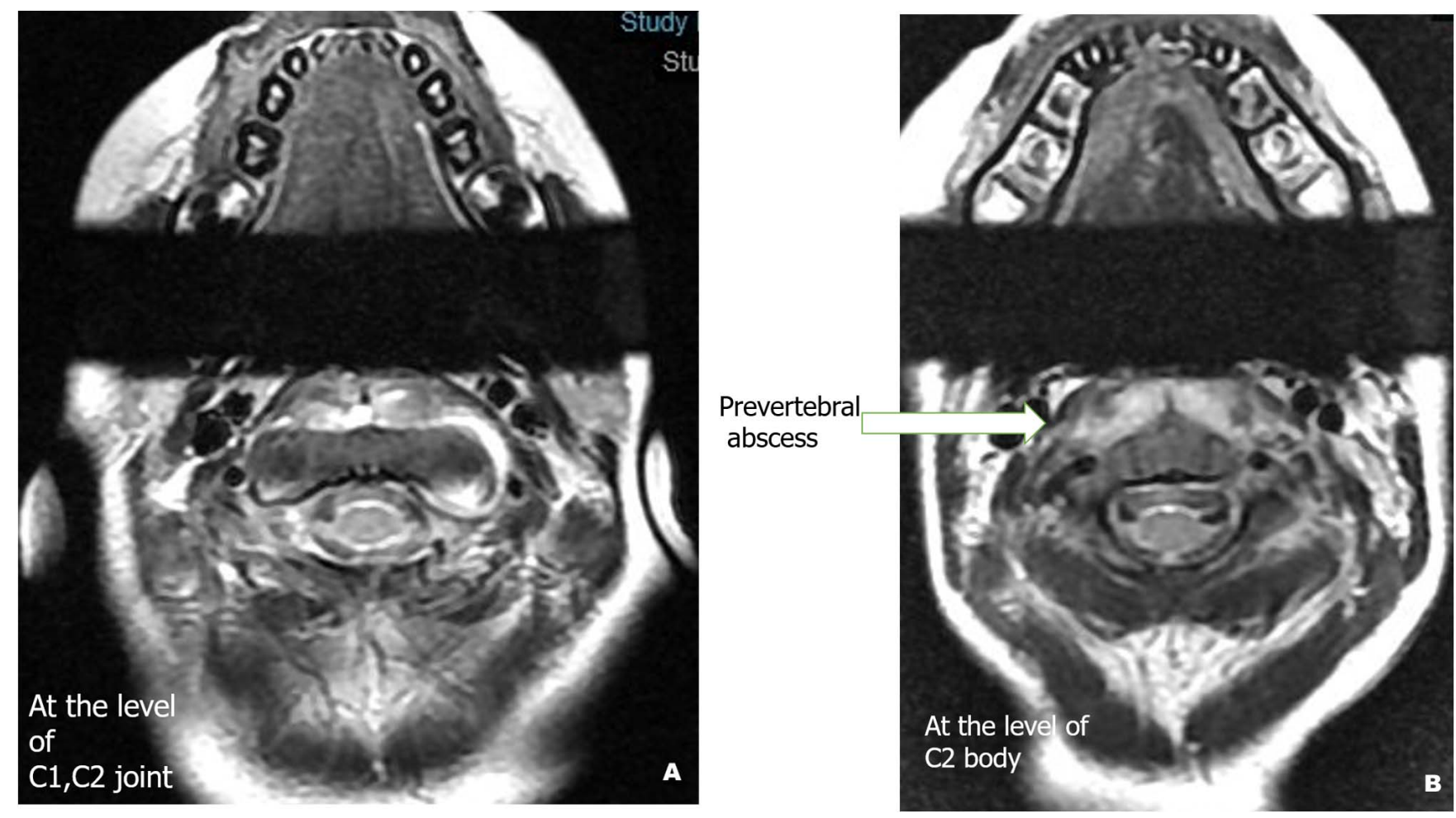

Figure 4. (A) and (B) T2 weighted axial magnetic resonance imaging (MRI) showing prevertebral abscess at $\mathrm{C} 1-2$ facet joint and at the level of $\mathrm{C} 2$ body respectively. 


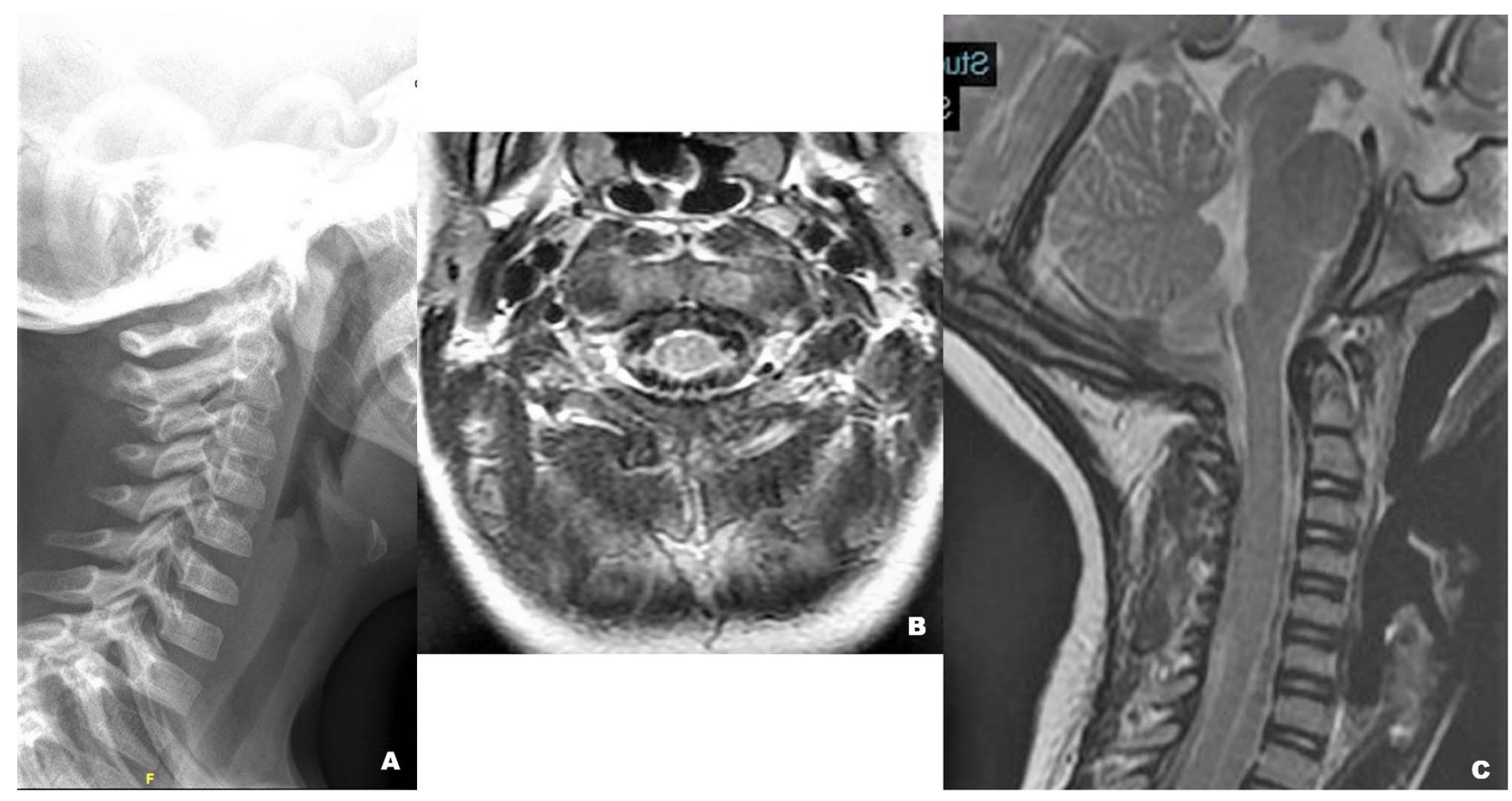

Figure 5. (A) Plain radiograph with restoration of cervical lordosis. (B)T2 weighted axial and (C) T2 weighted sagittal magnetic resonance imaging (MRI) with resolved abscess and presence of only thickened prevertebral soft tissue.

ing component in the prevertebral space at the level of C1-3 (Figures 3B, 4A,B). There was no atlantoaxial subluxation. His blood culture was positive for brucellosis, and the biochemical markers were elevated. He was treated with gentamycin injection for 3 weeks, rifampicin, trimethoprim TMP, and sulphamethoxazole SMX for 6 months.

He tolerated medications well and was healed of the disease. Posttreatment plain radiograph revealed restoration of normal cervical lordosis (Figure 5A). There was only residual soft tissue thickening in the prevertebral space with resolution of the abscess (Figures 5B,5C).

\section{REFERENCES}

1. Mirnejad R, Jazi FM, Mostafaei S, Sedighi M. Molecular investigation of virulence factors of Brucella melitensis and Brucella abortus strains isolated from clinical and non-clinical samples. Microb Pathog. 2017;109:8-14.

2. Aloufi AD, Memish ZA, Assiri A, McNabb SJ. Trends of reported human cases of brucellosis, Kingdom of Saudi Arabia, 2004-2012. J Epidemiol Glob Health. 2016;6(1):11-18.

3. Bakheet HG, Alnakhli HA. Brucellosis in Saudi Arabia: review of literature and epidemiology. $J$ Trop Dis. 2019;7(304):2. doi:10.4172/2329-891X.1000304

4. Gür A, Geyik MF, Dikici B, et al. Complications of brucellosis in different age groups: a study of 283 cases in southeastern Anatolia of Turkey. Yonsei Med J. 2003;44(1):3344.

5. Geyik MF, Gür A, Nas K, et al. Musculoskeletal involvement of brucellosis in different age groups: a study of 195 cases. Swiss Med Wkly. 2002;132(7-8]):98-105.

6. Brucellosis 2010 CSTE case definition. Centers for Disease Control and Prevention Web site. https://wwwn.cdc.gov/nndss/ conditions/brucellosis/case-definition/2010/. Accessed January 20, 2020 .

7. Maynard FM Jr, Bracken MB, Creasey G, et al. International standards for neurological and functional classification of spinal cord injury. American Spinal Injury Association. Spinal Cord. 1997;35(5):266-274.

8. al-Shahed MS, Sharif HS, Haddad MC, Aabed MY, Sammak BM, Mutairi MA. Imaging features of musculoskeletal brucellosis. RadioGraphics. 1994;14(2):333-348. doi:10. 1148/radiographics.14.2.8190957

9. Mirnejad R, Mohammadi M, Majdi A, Taghizoghi N, Piranfar V. Molecular typing of Brucella melitensis and $B$. abortus from human blood samples using PCR-RFLP method. Jundishapur J Microbiol. 2013;6(6):1-5.

10. Bosilkovski M, Krteva L, Dimzova M, Vidinic I, Sopova Z, Spasovska K. Human brucellosis in Macedonia-10 years of clinical experience in endemic region. Croat Med J. 2010;51(4):327-336.

11. Akbayram S, Dogan M, Akgun C, et al. An analysis of children with brucellosis associated with pancytopenia. Pediatr Hematol Oncol. 2011;28(3):203-208.

12. Elham E. Pediatric brucellosis: an update review for the new millennium. Saudi Med J. 2018;39(4):336-341.

13. Kaden R, Ferrari S, Jinnerot T, et al. Brucella abortus: 
determination of survival times and evaluation of methods for detection in several matrices. BMC Infect Dis. 2018;18(1):259. doi:10.1186/s12879-018-3134-5

14. Lubani M, Sharda D, Helin I. Brucella arthritis in children. Infection. 1986;14(5):233-236. doi:10.1007/ BF01644269

15. Esmaeilnejad-Ganji SM, Esmaeilnejad-Ganji SMR. Osteoarticular manifestations of human brucellosis: a review. World J Orthop. 2019;10(2):54-62.

16. Hashemi SH, Keramat F, Ranjbar M, Mamani M, Farzam A, Jamal-Omidi S. Osteoarticular complications of brucellosis in Hamedan, an endemic area in the west of Iran. Int J Infect Dis. 2007;11(6):496-500.

17. American Academy of Pediatrics. Pickering LK, Baker CJ, Kimberlin DW, Long SS, eds. Red Book: 2009 Report of the Committee on Infectious Diseases. 28th ed. Elk Grove Village, IL: American Academy of Pediatrics; 2009.

18. Al-Tawfiq JA. Therapeutic options for human brucellosis. Expert Rev Anti Infect Ther. 2008;6(1):109-120.

19. Bosilkovski M, Kirova-Urosevic V, Cekovska Z, et al. Osteoarticular involvement in childhood brucellosis: experience with 133 cases in an endemic region. Pediatr Infect Dis J. 2013;32(8):815-819.

20. Yilmaz B, Ozdemir G, Aktas E, Komur B, Alfidan S, Memisoglu S. Brucellosis suspicion is the most important criterion for diagnosis particularly in endemic regions. Open Orthop J. 2016;10:7-11.

Disclosures and COI: This research received no specific grant from any funding agency in the public, commercial, or not-for-profit sectors. The authors report no conflicts of interest.

Corresponding Author: Justin Arockiaraj, MS, Spine Surgery Department, National Neurosciences Institute, King Fahad Medical City, P.O. Box. 59046, Riyadh 11525, Kingdom of Saudi Arabia. Phone: 0096650627 7983; Email: svjustin. arockiaraj@gmail.com, javincent@kfmc.med.sa.

Published 19 August 2021

This manuscript is generously published free of charge by ISASS, the International Society for the Advancement of Spine Surgery. Copyright (C) 2021 ISASS. To see more or order reprints or permissions, see http://ijssurgery.com. 